Comment on 'I, Sex Robot: the health implications of the sex robot industry'

In their editorial, ${ }^{1}$ Cox-George and Bewley promote a one-sided and negative view of sex robots ('sexbots'), which they describe as "realistic mannequins with variable ages, appearances and textures, and customisable oral, vaginal and anal openings". Three things about this editorial particularly concern me.

First, Cox-George and Bewley seem to have constructed a series of objections to sex robots based on their dislike and disapproval of them. Their editorial is full of medico-political attempts 
to stigmatise or even criminalise those who use sex robots - with arguments about "misogynistic objectification" of women and intensification of "existing physical and sexual violence against women and children". 1

Why should the use of an entirely synthetic, non-human sex robot have any negative connotations? Why is it misogynistic even if sex robots, like sex dolls, are going to be predominantly used by heterosexual men? 'Female' sex robots are not women. And what about the use of 'male' sex robots by homosexual men? Does that objectify homosexual men? Would the use of female sex robots by lesbian women objectify lesbian women?

Second, the underlying purpose of Cox-George and Bewley's editorial seems to be to establish themselves as the moral arbiters of sex robot use. This is revealed in the penultimate paragraph of their conclusions, where they say: "The UK General Medical Council and medical defence organisations have not issued any guidance but doctors might be advised to avoid using sexbots themselves, given police interest, prosecutions and the potential negative impact on public trust". 1

They do not cite any evidence to support such intimidatory and threatening advice. They mention one prosecution of a person who imported a "child sex doll", but, as they say in their opening paragraph, sex robots resembling children, which would obviously be of interest to paedophiles, must be considered separately from adult sex robots. To intimidate and threaten doctors in this way is totally unacceptable. The sexual practices and preferences of doctors - so long as they remain legal - should have nothing to do with the General Medical Council (GMC). Unless we are taking the power of the GMC to a new 'Big Brother' level, God forbid.

Third, Cox-George and Bewley's assessment of sex robots does not take into account the position of a significant proportion of adult men (and presumably women) who, because they have physical (or mental) issues or disease, have no prospect of a sexual relationship with another human being apart from a sex worker.

I am fortunate in being a happily married man, with no interest in personally using sex dolls or robots, but as a general practitioner I have been consulted on many occasions by men whose prospects of having a sexual relationship with a woman are essentially zero. These men have no choice but to visit sex workers if they want sex with a real woman, and I have witnessed the consequences that they have suffered in terms of resulting sexually transmitted diseases and associated social problems. If they prefer to use a sex robot to fulfil that need, there is no reasonable argument against them doing so, and there are plenty of arguments why the use of a sex robot might be preferable to visiting a sex worker (without in any way stigmatising the use of sex workers).

Doctors in general should "live and let live" and avoid being judgmental. Society has already had to learn the lesson of tolerance about homosexuality and transgender people. Are we really going to have to learn this lesson all over again about sex robots?

\section{John Eggleton}

Correspondence to Dr John Eggleton, Exeter EX5 5HN, Devon, UK; jdp. eggleton@btinternet.com

Competing interests None declared. Patient consent Not required.

\section{Provenance and peer review Not} commissioned; internally peer reviewed.

(c) Author(s) (or their employer(s)) 2019. No commercial re-use. See rights and permissions. Published by BMJ.

\section{D) Check for updates}

BMJ Sex Reprod Health 2019;45:78-79. doi:10.1136/bmjsrh-2018-200251

\section{REFERENCE}

1 Cox-George C, Bewley S. I, Sex Robot: the health implications of the sex robot industry. BMJ Sex Reprod Health 2018;44:161-4. 